\title{
Uma discussão sobre o artigo "Ideias imperativas"1, do Dr. Hack Tuke ${ }^{2^{*}}$
}

\author{
Dr. Hughlings-Jackson \\ Dr. G. H. Savage \\ Dr. C. Mercier \\ Dr. J. Milne Bramwell
}

\section{Nota do Editor Responsável}

Esta é a segunda parte do artigo de Hack Tuke sobre "Ideias imperativas", publicado, originalmente, na revista Brain, em 1894.

Este tipo de "discussão" ocorria quase exclusivamente na Inglaterra, onde as sociedades científicas tinham grande importância, talvez tão grande quanto as universidades, para o avanço do conhecimento científico.

Agradeço especialmente ao Prof. Dr. German E. Berrios por ter selecionado este longo e importante artigo para ser publicado na seção "Clássicos da Psicopatologia" da Revista Latinoamericana de Psicopatologia Fundamental. A generosa colaboração do Prof. Berrios e do grupo de Cambridge engrandece nossa revista.

$1 \mathrm{O}$ artigo "Ideias imperativas" foi publicado $\mathrm{Na}$ Revista Latinoamericana de Psicopatologia Fundamental, 16(4), 615-629, dez.2013.

${ }^{2}$ Desde o recebimento dos presentes artigos pelo editor, lamentamos com pesar o recente falecimento do Dr. Hack Tuke, o qual tinha a intenção de sintetizar a discussão respondendo a algumas das críticas a ele endereçadas.

* Tradução de Luana Villac. 


\section{Dr. Hughlings-Jackson}

Embora não tenha tido o prazer de estar presente à apresentação do importante artigo do Dr. Hack Tuke, eu o li e gostaria de tecer alguns comentários sobre o mesmo. Após atenta leitura, posso afirmar que já me deparei, em diversas ocasiões, com o que o Dr. Tuke denomina "ideias imperativas". Infelizmente, dei pouca atenção a esses casos do ponto de vista científico e certamente não os considerei a partir de uma perspectiva ampla, tal qual a apresentada pelo Dr. Tuke com tanta habilidade. Estou seguro de que os neurologistas tirarão grande proveito de suas pesquisas sobre esse curioso e importante tema. Algo que me causa viva impressão é o fato de o Dr. Tuke lidar com os casos de ideação mórbida enquanto fugas de estados mentais normais, ou, pelo menos, enquanto exageros e persistências de estados mentais os quais, em sua origem, seria pedante classificar como anormais.

$\mathrm{Na}$ apresentação de Leeds (British Medical Journal, vol. I, 1889) à qual o Dr. Tuke faz referência, sugeri que certos delírios persistentes e deveras absurdos devem-se à fixação de fantasias oníricas grotescas em casos nos quais uma alteração mórbida no cérebro ocorre repentinamente, ou aumenta de súbito durante o sono. Não aplicarei esta hipótese a todos os casos relatados pelo Dr. Tuke. É possível, porém, que determinados pensamentos intrusivos que a princípio seriam transitórios tornem-se fixados, tornem-se "ideias imperativas", como consequência de alguma ligeira alteração mórbida ocorrida no cérebro durante o sono. Com efeito, suponho que, para o Dr. Tuke, um estado normal, ou pelo menos um estado ordinário em pessoas consideradas saudáveis, torna-se mais ou menos fixo quando a saúde geral é reduzida ou quando uma alteração mórbida praticamente insignificante ocorre no próprio cérebro. Sobre o que denomina "Pavor de Sujeira", o Dr. Tuke escreve: "Em caso de redução do poder mental geral ou da existência de uma predisposição hereditária, esta tendência a se ocupar do estado da pele torna-se uma paixão, resultando nas desnecessárias e cansativas lavagens do corpo ou das vestimentas. 


\section{CLÁSSICOS DA PSICOPATOLOGIA}

De fato, muitas vezes o paciente acaba por não mais perceber a insensatez dessas abluções e enfrenta um delírio real." Certamente temos que levar em consideração a existência destes estados quase parasitários nos casos em que o poder mental geral é apenas ligeiramente reduzido. As seguintes observações feitas pelo Dr. Tuke vão ao encontro dessa colocação e ilustram minha afirmação sobre sua concepção das "ideias imperativas" enquanto fugas de estados mentais normais ou quase normais (grifo meu): "O que inevitavelmente impressiona sobre a maior parte, senão sobre todas as ideias imperativas, é que entre estas e as ideias ordinárias, a diferença é de grau, e é muito difícil determinar quando a fronteira é ultrapassada. Isso no que diz respeito ao aspecto psicológico. Quanto ao aspecto físico, o que queremos saber acima de tudo é qual mudança cerebral, degeneração ou dissolução ocorre para que um homem que hoje está consciente e sorri perante uma ideia imperativa, amanhã acredite nela gravemente, e fique subjugado a um delírio sistematizado". Mais à frente, o Dr. Tuke afirma: "A ideia predominante tornou-se, de fato, parte de seu (do paciente) próprio ser". Trata-se, assim, de um estado mental quase parasitário do paciente, conforme evidenciado pela expressão "ideia predominante" usada pelo Dr. Tuke.

Na já citada apresentação de Leeds, falei sobre "fixação de estados" em lesões ocorridas subitamente em casos onde não há alienação; na afasia, por exemplo.

Penso que o Dr. Tuke acertou ao focar sua atenção não apenas nas extensas pesquisas anteriores realizadas por Laycock, mas também nos importantes princípios mais recentemente estabelecidos por Anstie e Thompson Dickson e por Monro. Monro, até onde sei, foi o primeiro a enunciar que nos casos de alienação a condição mental anormal é dupla, sendo formada por dois elementos opostos, um negativo e um positivo (Há, evidentemente, a óbvia exceção da demência completa — demência profunda na qual a condição mental é inteiramente negativa). De minha parte, considero que ilusões, delírios e todos os outros sintomas mentais positivos na alienação denotam atividades de arranjos nervosos saudáveis dos mais elevados centros cerebrais (o assim chamado "órgão da mente"). O que chamamos de ilusões de um homem alienado são suas percepções; o que chamamos de delírios são suas crenças e, de modo mais abrangente, seus sintomas mentais positivos fazem uso da atividade mental restante que lhe é possível e que ocorre durante as atividades do que foi deixado intacto em seus centros superiores, isto é, daquilo que a doença poupou. A condição física para esses sintomas mentais positivos não é causada, tomando a palavra "causa" em seu sentido estritamente científico, pela doença, ou seja, não é causada por um processo patológico. A doença responde apenas, no meu entender, pelo elemento mental negativo coexistente na alienação. Devo acrescentar que um estado mental positivo implica um coexistente estado mental negativo; se um homem vê um gato preto onde há apenas um chapéu de feltro preto - para tomarmos um tipo de sintoma mental, a ilusão — não apenas há para ele ali um gato preto, mas também não há chapéu de feltro algum. $\mathrm{O}$ mesmo se dá, mutatis mutandis, com outros sintomas mentais positivos fazendo uso 
do elemento positivo da alienação de um paciente. Quanto ao aspecto físico, distúrbios na camada mais elevada dos centros mais elevados produzindo perda de função ou destruindo-a respondem pelo elemento mental negativo em caso de alienação, enquanto a atividade das camadas inferiores intactas responde pelo elemento mental positivo. Às vezes, porém, os sintomas positivos são superpositivos, como na inconsciência pós-epilética (elemento negativo) com mania (elemento positivo). Nestes casos, as áreas inferiores estão excessivamente ativas, mas ainda assim acredito que estão saudáveis, que permanecem intocadas pelo processo patológico que produziu a perda da função ou destruiu a camada superior. Sua atividade em excesso é um estado hiperfisiológico análogo ao aumento da frequência das batidas do coração após secção do nervo vago. Aplica-se aqui o princípio de Anstie. A perda de função ou destruição da camada mais elevada dos centros mais elevados é não apenas uma perda (respondendo ao elemento mental negativo de uma alienação), mas é também uma retirada de controle das cadeias inferiores; enquanto a superior "retira", a inferior "solta". Pode-se dizer que o distúrbio é "construtivamente responsável" pela superatividade das camadas inferiores, uma vez que se a doença não houvesse destruído a camada superior, esta teria permanecido no controle das camadas inferiores.

Já sugeri em outras ocasiões que a velocidade com que este controle é removido é um fator importante na alienação — as camadas inferiores apresentam, ao menos temporariamente, maior atividade quanto mais rapidamente as camadas superiores perdem sua função ou são destruídas. Quando a doença da camada superior progride muito lentamente pode não haver nenhum sintoma mental positivo intrusivo (o controle é removido lentamente); quanto ela progride muito rapidamente a atividade mental do paciente (atividade mental restante que lhe é possível) ocorre em grande velocidade (o controle é removido rapidamente). ${ }^{3}$

Em relação ao que o Dr. Tuke afirma em seu primeiro parágrafo, sou da opinião de que o estudo científico das alienações pode ser melhor conduzido inicialmente em hospitais gerais, já que nestes encontramos casos em que há desvios leves do estado mental normal do paciente e quanto mais ligeiro o desvio, mais facilmente pode ser analisado. Tentei ilustrar essa questão ("Neurological Fragments," British Medical Journal, 5 de março de 1892). Vemos, todavia, nesses hospitais, todos os graus de desvios de estados normais, desde leves confusões de pensamento temporárias até o coma profundo. Devemos estudar casos de desvios de estados normais independentemente de constituírem ou não casos de insanidade, conforme são chamados em linguagem corrente, delírios em doenças agudas não cerebrais, a pneumonia, por

${ }^{3}$ Não entrarei em detalhes aqui, já que recentemente (junho de 1894) publiquei um artigo no Medical Press and Circular sobre "Os fatores nas alienações". 


\section{CLÁSSICOS DA PSICOPATOLOGIA}

exemplo. Devemos, acredito, encontrar nos graus de alienação que se apresentam algum índice da condição geral dos pacientes e, assim, alguma orientação para o tratamento destes casos. Penso que podemos aprender algo de grande valor com a investigação analítica da condição mental anormal em certos casos de intoxicação por cannabis indica e por belladonna. O Dr. H. C. Wood, em seu trabalho "Sobre terapêuticas" registra suas experiências após ingerir uma dose grande de cannabis americana. Um estudo cuidadoso da condição mental anormal registrada por esse distinto médico será, na minha opinião, mais proveitoso do ponto de vista científico do que a maior parte dos casos ordinariamente chamados de alienação. Ele descreve, entre outras coisas, a "sensação de prolongamento do tempo", um tema de grande interesse psicológico; este prolongamento do tempo ocorre nos sonhos e, em alguns casos, no delírio comum.

Em alguns casos de tumor intracraniano, há uma redução geral da mente, ou, em sinonímia, da consciência, em direção à completa demência, e por vezes bastante próxima dela. Temo, entretanto, que não estejamos dando suficiente atenção à falência mental leve. Acredito que o grau de degradação mental será útil na avaliação da condição do paciente, especialmente no que diz respeito ao grau do aumento da pressão intracraniana provocado pelo tumor. Eis aqui uma questão prática extremamente importante e de urgente interesse, agora que Victor Horsley colocou a questão da pressão intracraniana em uma, digamos, nova e definitiva base em relação a vários sintomas importantes da doença cerebral. Arrisco-me a afirmar que pode vir a ser dito sobre os casos em que houve apenas pronunciado torpor ou grande obtusidade que não havia sintomas mentais. Isso seria bastante descuidado, já que torpor e obtusidade são aqui sinônimos de defeito de consciência. Nestes casos, a condição mental negativa é mais ou unicamente pronunciada; sintomas mentais positivos são raros e eu suponho que isso aconteça porque a pressão intracraniana é lentamente aumentada, enquanto o cérebro é lentamente comprimido. Assim, o restante funcional do cérebro apresentará pouco ou nenhum excesso de atividade, sendo o controle lentamente removido.

\section{Dr. G. H. Savage}

Após ter escutado a leitura completa do artigo deveras sugestivo do Dr. Hack Tuke, sinto que o que tenho a dizer é, acima de tudo, um complemento ao que foi tão bem colocado, ao mesmo tempo em que ofereço também minha experiência particular dos últimos vinte anos. Em primeiro lugar, o termo ideias "imperativas" é, sob um aspecto, enganoso, pois, embora essas ideias sejam amiúde impositivas, nem sempre são elas a fonte da ação; de certa forma elas comandam, mas comandar implica esperar algum resultado deste comando, e há pacientes que possuem ideias dominantes há anos 
sem nunca ter sentido que estas possuam qualquer relação com suas ações ou conduta. Algumas ideias imperativas são sugestivas e outras são impositivas.

Quanto à sua causa, na minha experiência, a causa predisponente mais comum é a predisposição hereditária, certas neuroses ou a tendência à degeneração nervosa presente nos parentes dos pacientes, ou alguma outra evidência marcante de instabilidade nervosa em irmãos, irmãs ou primos.

Quanto às causas excitantes, ou, se posso usar esta terminologia, o determinante da forma da ideia imperativa, já me deparei com diversos casos que pareciam corresponder a um crescimento mórbido estável que durante muito tempo permanecera sob a superfície, mas, por algum motivo acidental, foi trazido à luz do dia. $\mathrm{O}$ choque pode produzir esse efeito. Pode ser um choque repentino, uma repetição de choques ou o resultado de um estado prolongado de expectativa e apreensão. Dessa forma, uma pessoa que esteve sob perigo iminente durante algum tempo pode ficar tão afetada que seu medo nunca é superado; aliado a isso, já encontrei casos nos quais um sonho extraordinariamente vívido foi suficiente para dar início a toda a corrente de ideias mórbidas, fixando-as para sempre. Não resta dúvida de que o sistema nervoso, submetido a certas condições, fica mais propenso a tomar certas impressões e retê-las. É como se através de certas condições circundantes fosse criada uma impressão que alcançasse as partes mais automáticas e mais fixas do sistema nervoso, de modo que ela não é mais meramente armazenada para uso quando chamada pela consciência, mas surge como um ato reflexo, aparecendo sem nenhum exercício da vontade. Acredito que essas ideias imperativas sejam muito comuns, e que quase todo mundo possua algumas. Um homem não pode dissociar de sua mente noções que não possuem nenhuma relação aparente; provavelmente, elas surgiram no estágio pré-consciente, ou no estágio de desenvolvimento anterior ao estabelecimento da memória. Tenho uma sensação, comum, acredito, ao caminhar pela calçada. Fico inclinado a evitar as fissuras e ao mesmo tempo possuo uma tendência - não irresistível, admito - a tocar as grades de ferro com minha bengala; e mais: quase nunca adormeço sem que, pouco antes de ficar inconsciente, uma frase que não possui relação com nada em meu passado ou presente imponha-se à minha mente; então sei que estou prestes a dormir e se fiquei insone por algum tempo e esta frase veio a mim, sei que não estou longe de adormecer.

Na comparação entre mente e corpo, sabemos que o que é alimento para um homem é veneno para o outro, que uma coisa muito trivial aparentemente fará toda a diferença: enquanto o conforto de um depende de que não tome chá, o outro não suporta morangos. $\mathrm{O}$ corpo possui suas ideias imperativas e terei que me referir a ideias imperativas dos sentidos ou, antes, a sensações imperativas - uma pessoa é incapaz de suportar a presença de um gato enquanto outra é afetada por uma rosa. De fato, os sentidos oferecem valiosa ajuda na consideração desta questão, pois não apenas podemos ver que essas influências imperativas nervosas podem ser primárias, como o cheiro do gato, mas que podem ser secundárias ou associadas. Nesse sentido, no assim 


\section{CLÁSSICOS DA PSICOPATOLOGIA}

chamado fotismo, determinadas pessoas possuem associações com uma sensação que não possui nenhuma relação real com ela. Por exemplo, um homem ouve um som de vogal e vê uma determinada cor ao mesmo tempo, enquanto outro sentindo certo cheiro também vê uma cor surgir com a sensação olfatória. Essas relações de sentidos são bastante imperativas e se estabelecem tão cedo que a maioria daqueles que as têm não conseguem retornar a nenhum momento em que estavam livres delas.

A maior parte dos livros recentes sobre este tema demonstra uma relação bastante próxima entre essas ideias imperativas e a condição neurastênica, e que a neurastenia depende em grande parte, se não completamente, de uma falha na associação de ideias. Este processo foi assim descrito: "No curso ordinário de ideação agindo ao longo de linhas comuns de associação, uma ou mais ideias inserem a si próprias e permanecem na consciência com mórbida intensidade e persistência". Tais ideias diferem de delírios, alucinações ou ilusões pelo fato de o paciente reconhecê-las como falsas. Pacientes podem ter alucinações e ilusões e não acreditar nelas, mas estas possuem uma relação com a mente diferente das sensações persistentes do paciente acometido pela desordem imperativa; as alucinações são menos regulares em sua reincidência e não são necessariamente iniciadas a partir de uma impressão sensorial externa. As ideias imperativas variam em grau. Sob determinadas condições uma palavra pode inserir a si mesma sempre, ou pode parecer escapar sempre que buscada, deixando um deplorável sentimento de vazio que impede qualquer descanso. Isso é, por um lado, como a doença da dúvida, à qual nos referiremos mais adiante. Além da simples inserção ou fuga de palavras, a palavra pode trazer sempre uma associação desagradável; assim, a ideia de sujeira, sangue, impureza, moral ou religiosa, pode surgir, ou algumas melodias podem brotar sem nenhum excitante reconhecido. Há outras formas associadas de desordem, nas quais não apenas está presente a associação mórbida, mas também uma tendência a agir sobre a ideia. Elas são o que um paciente em Bethlem, que era muito impulsivo e perigoso, chamou de "consciência sugestiva". Uma ideia lhe vinha à mente e ele precisava passar à ação imediatamente. No seu caso havia um reflexo mental incontrolado, a ideia sugeria a ação sem nenhuma consideração com as consequências. Outros exemplos são pessoas afetadas por alturas, trens passando rapidamente e afins. Acredito que quase todos os casos deste tipo pertencem a famílias extremamente neuróticas. Eu me surpreendi com o pavor extremo de altura e movimento presente em pessoas que eu sabia serem neuróticas. Algumas destas pessoas sofrem do medo de que vão passar das ideias para a ação - enquanto uma teme uma lâmina ou uma corda, outra evitará crianças para não empurrá-las para o penhasco. Em outros casos temos noções mais organizadas e termos já cunhados para expressá-las. Pessoas que têm medo da solidão e aquelas que evitam as multidões são descritas como claustrofóbicas e agorafóbicas, respectivamente. Recentemente atendi um clérigo que há anos é obrigado a ter sua esposa andando um metro atrás dele devido a uma sensação insuperável de que alguém vai lhe pular às costas. Sem dúvidas há diversas 
outras formas especiais que não parecem merecer nomes, contanto que sua origem seja reconhecida. $\mathrm{O}$ mais definitivo e elaboradamente organizado estado deste tipo é visto em muitos casos da assim chamada paranoia.

As ideias imperativas podem surgir principalmente com os sentidos. Já observei diversos casos nos quais a ideia de que havia agulhas e alfinetes em suas roupas tornou penosa a vida do paciente. Em um caso, uma jovem com neurose hereditária perguntava sem cessar se seria melhor vestir suas roupas sem examiná-las, permanecendo em dúvida sobre a presença dos alfinetes, ou se deveria passar meia hora procurando em vão pelos alfinetes e, ainda insatisfeita, vestir-se. Aconselhei-a a vestir-se sem maiores considerações e não posso dizer se este ou outro tratamento fez efeito, mas, de qualquer forma, ela se recuperou completamente. A sensação persistente de sujeira ou do contato contagioso são estados associados àqueles que mencionamos, diferindo apenas na explicação. Em um caso, uma senhora solteira de meia-idade passava todo seu tempo limpando os tesouros de sua casa, permanecendo ainda assim devastada por seu suposto estado de sujeira. Em outros casos, a sensação de que o contato com a maçaneta da porta pode transmitir veneno não é muito incomum; em muitos destes casos há algum vício sexual, ou pelo menos uma anormalidade sexual. Uma senhora solteira sentia-se infeliz horas após ter urinado ou tocado no vaso; ela tinha o hábito de usar luvas para evitar danos. Em outro caso, uma paciente usava luvas para impedir que suas mãos tocassem a genitália. Há diversas outras noções igualmente imperativas e igualmente desarrazoadas. Em outro caso um jovem saudável, a não ser por sua neurose hereditária, era assombrado pela ideia de que havia fogo à sua espreita em todos os lugares; quando em meu consultório, ele pensou que poderia haver fogo entre os livros sobre a mesa e pediu permissão para vê-los. Abriu as páginas de vários livros e acalmou-se por certo tempo, pedindo apenas uma vez mais para verificar se não havia ateado fogo por fricção nos livros que tocara.

Já afirmei antes que algumas ideias dominantes surgem do hábito, e suponho que todos nós já experimentamos a incerteza quanto à porta da frente estar trancada ou o gás desligado. Em alguns casos a alucinação pode tornar-se uma ideia imperativa e em um caso muito interessante a alucinação formou o que se pode chamar de cicatriz mental. Em um ataque de melancolia durante o puerpério, uma mulher viu a garganta de seu irmão cortada e sangrando, e ficou convencida de que ele havia cortado sua garganta devido à tristeza pela loucura da irmã. Nenhuma evidência de que seu irmão estava bem a satisfazia. Depois de meses de doença ela melhorou, mas a alucinação retornou como uma espécie de aviso quando, ao amamentar ou realizar atos similares, ela extenuava-se. Parecia haver um desnudamento expondo a cicatriz estabelecida. Semelhantes a essas ideias imperativas ligadas às sensações, não se deve esquecer certos casos hipocondríacos nos quais há apenas um conjunto de ideias mórbidas o qual, no entanto, domina e destrói a utilidade da vida. Há diversos médicos em Londres que possuem tais ideias imperativas: eles acreditam que estão morrendo, que seus 


\section{CLÁSSICOS DA PSICOPATOLOGIA}

cérebros não são iguais aos dos outros seres humanos, ou que seu sistema nervoso geral é único. Argumento nenhum os satisfaz. Em um aspecto, portanto, eles diferem de muitas pessoas que admitem que suas ideias sejam desatinadas, embora incontroláveis. Como regra geral, é mais comum se deparar com associações imperativas de ideias; estas podem estar ligadas de muitas maneiras, mas uma ideia traz à tona como uma certeza a que lhe corresponde.

Anos atrás tive sob meus cuidados um homem que, tendo vivido na Índia por alguns anos, esteve certa vez em grande perigo com outras pessoas, devido a um levante dos nativos. Era esperado que seu forte fosse invadido a qualquer momento, os homens mortos e as mulheres ultrajadas. Assim, foi acordado que os homens, caso se fizesse necessário, matariam suas mulheres e lutariam até a morte. Eles foram libertados, mas a associação entre esposa e matar ficou tão fortemente estabelecida que o paciente sentia que sua única segurança seria morar em um sanatório. Ele o fez até a morte de sua mulher; depois disso saiu de lá e viveu em liberdade.

A volição é afetada de diversas formas, mas a principal desordem aparece em alguns casos de dúvida, nos quais o paciente nunca consegue decidir-se sobre o que fazer. Em alguns casos as dúvidas relacionam-se a movimento. Tenho cartas nas quais os pacientes perguntam ininterruptamente se há algum dano em se locomover cada vez mais devagar, se com isso eles conseguem satisfazer-se.

Conheci um jovem deste tipo que quase perdeu a vida por não ter sido capaz de tomar uma decisão; no exemplo em questão, tratava-se de saber se deveria atirar em um urso, e se um companheiro seu não o tivesse feito, não lhe teria restado nenhuma chance.

Entre as ideias associadas que são imperativas algumas são fortemente ligadas à questão emocional. Já se tomou conhecimento de pacientes cujas emoções estavam de tal forma pervertidas, que invariavelmente riam quando deveriam demonstrar compaixão. Em alguns casos a atração sexual, que pode ser tanto normal quanto anormal, pode ser persistente, recorrente e dominante e algumas associações deste tipo são especialmente dignas de nota. Neste sentido, certas associações produzem ideias de impotência sexual, ou algumas ocorrências bem pequenas na fase inicial do casamento podem dar início a ideias imperativas que produzem aversão, ódio e impotência, o que vem a ser perigoso para uma ou ambas as partes. Um jovem casado acredita, a partir de certos atos, que sua mulher não é virgem, ou ele pode simplesmente pôr essa ideia na cabeça e ter sua vida dominada por isso.

Similarmente, o julgamento pode ficar suspenso, como na "folie du doute". Não tenho intenção alguma de presumir que as partes da mente são entidades separadas, mas é bom notar que certas faculdades são mais afetadas em certos casos que em outros. Em alguns casos está presente um espírito morbidamente científico. Um paciente que esteve sob meus cuidados em Bethlem não conseguia resistir à tentação de ler o que estivesse escrito em qualquer lugar, de modo que se houvesse um homem lendo 
uma carta, seja no trem, no ônibus, em uma casa ou sala de jantar, não podia evitar lê-la por cima de seu ombro. Ele foi atingido pelos donos das cartas diversas vezes, mas ainda assim sentia o sobrepujante desejo de saber. Ele é Grubelsuchtic. Já correu risco de vida por diversas vezes quando, ao ver um pedaço de papel em torno de uma roda de táxi, tentou pegá-lo, tendo ido para casa infeliz depois de falhar e voltado à noite para a rua na tentativa de achá-lo. Este homem encontra-se há 12 anos neste estado e de quando em quando vem ver-me, pois fico ansioso para acompanhar seu percurso. Ele não é mais tolo do que era antes e consegue ganhar a vida apesar de sua peculiaridade interferir na realização de seu trabalho. Quanto à possibilidade de cura das ideias imperativas, posso dizer apenas que, se estão ocorrendo há um ano ou mais, penso não haver nenhuma perspectiva de cura. Se são agudas e associadas a alguma causa específica, ou se associadas a um período da vida, como a adolescência ou menopausa, há uma leve esperança. Poucos destes pacientes precisam ser permanentemente internados em sanatórios; na realidade, muitos deles jamais precisarão de internação se seus amigos tiverem meios de mantê-los fora dos sanatórios.

A título de conclusão, em minha experiência tenho observado que há certos defeitos orgânicos nos nervos, associados a reações mentais anormais, que podem mostrar-se no aspecto orgânico ou visceral e no aspecto sensorial, seja de modo simples ou por associação; no aspecto voluntário, com impulsos mórbidos, e no aspecto intelectual, com um maior desenvolvimento da associação de ideias, sendo estas mais comumente chamadas ideias imperativas, embora não difiram dos distúrbios sensoriais ou viscerais.

\section{Dr. C. Mercier}

O aspecto mais marcante do artigo do Dr. Tuke é, para mim, a completa aceitação de uma doutrina na qual há muito acredito e defendo, mas que nunca antes, em meu conhecimento, havia encontrado adesões, qual seja, que alienação e desordem mental não são termos intercambiáveis, e que a desordem mental — grave e proeminente desordem mental — pode existir em uma pessoa sã sem que a questão da alienação jamais seja levantada. Outra de minhas doutrinas preferidas, sobre a qual estou plenamente de acordo com o Dr. Tuke, é a importância de observar os primeiros desvios da normalidade se quisermos descobrir a verdadeira natureza e origem da desordem mental. É nesse sentido que as observações do Dr. Wilks são tão interessantes. Que as formas triviais de obsessão às quais somos todos passíveis — a recorrência persistente e muitas vezes irritante de uma palavra, de uma linha de um poema, de notas de uma melodia na memória - são da mesma natureza que as mais graves ideias imperativas das quais o Dr. Tuke nos deu tantos exemplos, não há, penso eu, nenhuma dúvida, e é importante, portanto, notar sob quais condições essas formas triviais ocorrem. 


\section{CLÁSSICOS DA PSICOPATOLOGIA}

Falando de minha própria experiência, elas não ocorrem quando a mente está completamente ocupada e a atenção absorta em algum propósito intelectual - ler, escrever, fazer cálculos, jogar xadrez ou uíste. Tampouco ocorrem quando o corpo está inativo e a mente absorta em alguma cadeia de pensamentos - como numa estrada de ferro - e nem quando uma atividade corporal é acompanhada por perto de algum exercício de atenção, como nos jogos de bilhar, boliche etc. As condições sob as quais elas ocorrem, e sob as quais raramente deixam de ocorrer, correspondem aos momentos de realização de um trabalho corporal de caráter mais ou menos monótono que exige considerável atividade muscular e não requer atenção próxima nem incessante, mas que demanda determinado grau e frequência do exercício da atenção que nos impede de manter qualquer cadeia contínua e conectada de pensamentos para além daquela que devotamos ao que nos ocupa no momento. Trata-se, em suma, de quando estamos envolvidos em algum tipo de bricolagem, tais como carpintaria, marcenaria, jardinagem, trabalhos com ferro e outros metais e ocupações afins que essas cepas de reminiscências surgem e nos assombram, tornando-se, naquele momento, ideias imperativas. Se pudermos identificar as condições psicológicas alcançadas ao nos ocuparmos com esses trabalhos manuais, poderemos obter alguma compreensão sobre aquilo que permite a ocorrência da obsessão em suas formas mais graves.

Nos casos mais graves da doença devemos supor que uma porção local do cérebro chegou a um hábito de atividade espontânea que domina o controle das regiões mais elevadas às quais, pela posição anatômica, deveria estar sujeita; com o tempo, toda a energia concentrada e focada das regiões nervosas mais elevadas, cuja localização é a base fisiológica da vontade, não é suficiente para dominar a atividade rebelde desta seção indomável; se a ideia imperativa permanece como uma ideia, ou se encontra expressão em palavras ou atos, é somente uma questão de grau, e não afeta de modo algum a explicação do processo fisiológico que é a base tanto das ideias quanto dos atos.

A condição psicológica nas formas mais leves aqui mencionadas parece ser a seguinte: há um grau considerável de atenção alerta e, ao mesmo tempo, o estímulo real fornecido para a atenção é insuficiente para mantê-la ocupada. A atenção concentra-se no trabalho que está sendo realizado, não de forma contínua, mas em intervalos; e nos intervalos, quando não está tão ocupada, mas permanece alerta, o estímulo que a ocupa advém do campo da subconsciência; desta forma, os estados que normalmente deveriam ser subconscientes são trazidos à luz da consciência plena e tornam-se objeto da atenção sem orientação direta da vontade que, por sua vez, está ocupada com outra coisa. Desse modo, um estado que emergiu e se apresentou à atenção em um intervalo desocupado, tende - desde que o trabalho permaneça aproximadamente o mesmo - a repetir-se em obediência à lei da associação, e a imagem, a melodia, a forma das palavras que emergiram durante um desses intervalos de atenção desocupada tendem a ocorrer a cada repetição desses intervalos. Em resumo, a condição psicológica pode 
ser expressa como a captura da atenção durante a suspensão da vontade. Se tomarmos essa expressão e a aplicarmos aos casos mais sérios que foram apresentados, veremos que ela se aplica a eles também. Em todos os casos a ideia imperativa se impõe — se me permitem falar metafisicamente — sobre a atenção e não pode ser, ou pelo menos não é, excluída pela vontade. No que concerne ao objeto da atenção, a vontade está em suspenso.

O processo fisiológico que subjaz a essa condição psicológica parece ser o que segue: trata-se de um retorno aos casos triviais e quase normais da doença, casos nos quais uma ideia se repete com frequência e força excessivas durante a execução de algum tipo de trabalho manual. Os trabalhos manuais requerem e implicam grande atividade dos centros do meio. Ao mesmo tempo, os centros superiores são pouco solicitados. Nenhuma atividade geral, intensa ou generalizada dos centros que são os substratos das elaboradas operações intelectuais, e especialmente das operações verbais, é requerida, e o trabalho manual não oferece nenhuma válvula de escape para tal atividade caso ela venha a ser evocada. Todavia, a alta atividade dos centros do meio não pode continuar sem espalhar-se, até certo ponto, no sentindo ascendente, iniciando atividade nos centros mais facilmente descarregados e estáveis acima deles. Ela não pode ao menos deixar de evocar alguma atividade desses centros superiores naquelas pessoas nas quais a atividade desses centros superiores é habitualmente grande, e cuja tendência a ter essa atividade facilmente evocada é, consequentemente, grande também. Durante as operações de trabalho manual, alguns destes centros superiores são, por conseguinte, iniciados e, no caso suposto, eles são centros de substratos de expressão verbal. Formas de palavras - sucessões de palavras - surgem dessa forma na mente. Se esses centros superiores fossem a sede da atividade generalizada, procedendo normalmente, com seu foco oscilando de lá para cá enquanto sucessões multiformes de expressões verbais aflorassem, a atividade iniciada pela propagação da descarga a partir dos centros medianos seria em grande parte levada ao local de maior atividade, enquanto as ideias acompanhando o restante seriam dominadas pelas ideias mais vívidas e volumosas — tornadas possíveis por esse processo — permaneceriam subconscientes e jamais ocupariam a atenção. Mas uma vez que essas pequenas áreas, iniciadas pela propagação ascendente da descarga são praticamente os únicos espaços de atividade localizada nos centros superiores, as ideias por elas representadas são praticamente as únicas ideias verbais presentes na consciência; e, enquanto tais, apoderam-se da atenção a cada intervalo vago, e são, portanto, trazidas em destaque para frente. Esta concentração local de energia propagada, que é o equivalente fisiológico da vontade, é direcionada para as camadas médias, passando a dirigir a operação de trabalho manual. Ela passa pelos centros articulatórios ativos, deixando esta última descoberta em seu volume premente, livre para se afirmar, para criar um centro de descarga quase isolado e, de certa forma, independente, que encontra seu equivalente mental na ideia imperativa. 


\section{CLÁSSICOS DA PSICOPATOLOGIA}

\section{Dr. J. Milne Bramwell}

Na conclusão de seu interessante artigo sobre ideias imperativas, o Dr. Hack Tuke afirma que os fenômenos mentais por ele descritos foram mais claramente reconhecidos por autores franceses e alemães do que por seus colegas ingleses. A afirmação está, sem dúvida, correta, porém, embora os primeiros tenham há muito reconhecido tal condição, foi apenas comparativamente há pouco tempo que eles, assim como nós, deixaram de confundi-la com diversas outras formas de alienação. O Dr. Ladame, de Genebra, por exemplo, ao referir-se às diferentes opiniões expressas por Schüle, Magnan, Krafft-Ebing, Marcé, Jules Falret, Morel, Lasègue, Ball, Meynert, Kraepelin e Scholz, sobre a "folie du doute" e o "délire de toucher", afirma que a primeira é vista pelos autores contemporâneos ora como um sintoma das mais variadas afecções mentais, ora como um episódio psicopatológico de degeneração hereditária, ora como uma forma especial de psicose e amiúde como um simples distúrbio psíquico elementar dependente da patologia geral da alienação mental. Assim, a dúvida, diz ele, não existe somente entre os pacientes, e poderia igualmente ser chamada de "folie $d u$ doute" tanto devido ao lugar incerto que ocupa no catálogo das doenças mentais quanto pelos estranhos sintomas que a caracterizam.

Segundo Ladame, Pinel começou a reconhecer a "folie du doute" no início deste século, enquanto Esquirol publicou em 1838 a primeira observação clínica detalhada do "délire du toucher", acentuando a luta constante do paciente contra as obsessões e seu reconhecimento do caráter absurdo das mesmas. Brierre de Boismont também afirmou, em 1853, que a ideia irresistível ardentemente combatida pelo paciente era característica desses casos. "Há uma distinção a fazer", afirmou ele, "a saber, que ideias podem adoecer alguém quando dominam a mente, mas ninguém está, de fato, louco, exceto quando a vontade torna-se impotente para controlar os impulsos". O fato de os pacientes lutarem contra suas obsessões sem conseguirem livrar-se delas foi particularmente sublinhado no debate sobre monomanias na Sociedade Médica-Psicológica de Paris em 26 de junho de 1854. Em 1859, Delasiauve fez uma primeira tentativa de estabelecer uma distinção entre pseudomonomanias e as formas reconhecidas de alienação. Depois de 1860, observações sobre o "délire du toucher" tornaram-se mais numerosas e Baillarger parece ter sido o primeiro a notar que esta condição se inicia com frequência na puberdade. Em 1882, Marcé descreveu claramente a origem das ideias imperativas, embora tenha deixado de fazer a distinção entre o "délire de toucher" e a alienação. "Em uma pessoa pré-disposta", afirma ele, "de caráter fraco, dotada de sensibilidade aguda, uma palavra, uma emoção, um medo, um desejo, deixa um dia uma impressão profunda. O pensamento gerado desta maneira apresenta-se à mente de forma insistente, toma posse dela e, sem deixá-la, domina todos os seus pensamentos; durante esse período, o indivíduo pode ter consciência do caráter 
absurdo, irracional e criminoso dessa ideia, e os próprios atos entram em conformidade com essas preocupações não saudáveis, tornando-se absurdos e extravagantes". O termo "folie du doute" surgiu pela primeira vez na celebrada discussão sobre a "manie raisonnante" na Sociedade Médica-Psicológica de Paris em 26 de março de 1866, mas de acordo com o que foi dito por Jules Falret na ocasião, é evidente que o que foi chamado de "folie du doute" correspondia ao "délire du toucher" e não à forma de distúrbio mental descrita dois anos depois por Griesinger como "Grübelsucht" e "Krankhafte Fragesucht". Nessa discussão Baillarger afirmou que uma de suas pacientes fazia suposições incessantes, perdendo-se no uso de "se" e "talvez". Uma distinção clara entre essas doenças e formas conhecidas de alienação foi feita pela primeira vez em 1886 por Morel, o qual afirmou que pacientes sofrendo de ideias imperativas não interpretam suas obsessões tais quais os alienados, que eles não experienciam nem alucinações nem delírios e tampouco passam pelas transformações que mudam a personalidade dos alienados, tornando-os radicalmente diferentes de quem eram antes. A hereditariedade, não apenas alienação hereditária, mas também outras condições nervosas como a histeria e a hipocondria, eram vistas por ele como importante causa de excitação. Em 1868, Griesinger publicou pela primeira vez casos que mostravam que a doença toda poderia consistir em questões insolúveis que sem cessar perseguiam os pacientes, os quais não conseguiam escapar dos "porquês" e "comos", e considerou que a condição poderia ser independente de questões emocionais. Em 1875, Legrand du Saulle mostrou que os mesmos pacientes podiam mostrar sucessivamente sintomas de "folie du doute" e de "délire du toucher" e, ao unir essas duas condições, tentou formar uma afecção mental especial dotada de uma verdadeira entidade mórbida. Em 1877, Westphal publicou uma importante contribuição ao assunto. De acordo com ele, a obsessão nunca se torna uma verdadeira "idée fixe délirante", mas sempre permanece estranha ao ego do paciente, enquanto os alienados amoldam-se logicamente às deduções de suas ideias fixas. Essa distinção científica entre ideias fixas e obsessões é reconhecida há muito tempo pela Igreja, que sempre diferenciou a obsessão da possessão, dizendo, por exemplo: "este homem não está possuído, ele está apenas sofrendo de obsessão". Segundo Westphal, uma obsessão não é uma emoção, nem jamais é produzida por uma, e se ataques de agonia mental aparecem mais tarde, são sempre secundários e simplesmente fenômenos concomitantes. Esta opinião é oposta às observações de Morel e dos eruditos franceses. Wille defende que as obsessões podem ter uma base emocional e acredita que às vezes são sucedidas por alienação mental verdadeira, enquanto Westphal afirma que casos de obsessão nunca se tornam alienação. Wille, bem como Legrand du Saulle, observou ideias suicidas frequentes, e até mesmo tentativas de suicídio, por vezes seguidas de morte, e considera a "folie du doute" e seus similares como uma condição intermediária entre as neuroses e as psicoses, e que a obsessão está sempre pronta para se transformar em loucura. 


\section{CLÁSSICOS DA PSICOPATOLOGIA}

Westphal divide as obsessões em três tipos: (1) permanecem em um plano puramente teórico, como a "folie du doute", quando tomam a forma de questões; (2) produzem certas ações, como o "délire du toucher"; (3) obsessões impulsivas, que provocam ações imediatas.

Desde Morel, diversos autores têm enfatizado a hereditariedade como fator essencial nas obsessões, mas Magnan parece ter sido o primeiro, em 1885, a considerar o distúrbio mental um signo direto e imediato de hereditariedade mórbida.

Em oposição a Legrand du Saulle, Ladame defende a separação da "folie du doute" e do "délire du toucher" em duas variedades clínicas distintas. Segundo esse autor, estas são sem dúvida associadas com frequência, assim como a pleuropneumonia, mas existem mais comumente isoladas. Para ilustrar sua posição ele cita os seguintes casos:

(1) Um jovem de 28 anos sofria do medo da contaminação e frequentemente lavava suas mãos como método de purificação. Ele nunca temia que viesse a esquecer algo e nunca levantava questões para si mesmo. Segundo Ladame, este era um caso de "délire du toucher" sem "folie du doute".

(2) A senhorita , 33 anos, desde a infância tivera ideias das quais não conseguia se livrar. Ela fazia a si mesma todo tipo de perguntas, procurando em vão pelas respostas. As questões se referiam particularmente ao outro mundo e à Criação. Tudo o que existe fez a si mesmo? Deus criou todas as coisas? O mundo não fez a si mesmo? Deus existe? Como se pode dividir objetos em partes infinitamente menores quando cada pequena parte pode ainda ser dividida? Como um objeto infinitamente dividido pode ainda ser dividido, embora não se possa dividi-lo mais? Pode Deus dividi-lo ainda mais? Somente Deus pode dividi-lo e, no entanto, essa partícula não pode ser dividida. Como se explica isso? Ela nunca sofreu de "délire du toucher".

Van Eeden afirma que em quatro casos tratados por ele não resta dúvidas sobre a conexão entre o "délire du toucher" e a "folie du doute", e que em todos esses casos a "folie du doute" evoluiu após o "délire du toucher", sendo uma evidente consequência deste. Um dos casos iniciou-se com o medo de contaminação por sífilis. O paciente evitava tocar em qualquer coisa que suspeitava que estivesse contaminada e, caso isso acontecesse, lavava suas mãos escrupulosamente. Suas preocupações tornaram-se exageradas, e ele não apenas duvidava de sua eficácia, mas também da clareza de seu julgamento, e apesar da excessiva atenção dada a essas abluções, não podia obter a certeza da completa limpeza. Uma evolução progressiva similar foi observada, segundo van Eeden, em uma paciente que sofria a princípio de "crainte de souillure", em seguida de dúvidas e finalmente de desconfiança de si mesma. O "délire du toucher" teve início com o medo de sujar sua comida - ela lavava as mãos incessantemente, mas a dúvida retornava. Outra paciente, que cuidava de um caso de câncer, ficou com medo de contrair a doença. Ela lavava as mãos constantemente e evitava o contato com pessoas das quais suspeitava.

$\mathrm{Na}$ agorafobia, claustrofobia etc. van Eeeden afirma que a ideia do medo surge repentinamente a partir da impressão do ambiente e é só depois disso que o paciente 
evita espaços abertos ou fechados. Aqui é o medo que causa a obsessão. Ele classifica como segue estas e outras condições similares: (1) "Conceptions obsédantes" — a obsessão surge de uma concepção detalhada e precisa de algum ato que adquire força impulsiva. (2) "Émotions obsédantes" — principalmente terror, no qual uma emoção momentânea, uma impressão — que um homem normal pode igualmente experimentar, mas reprime rapidamente - domina a volição e a razão. O paciente não consegue dizer do que tem medo, ou, se fornece uma razão, é evidente que ela foi inventada. (3) "Impulsions obsédantes" — tendência irresistível a cometer atos estranhos ou impróprios. (4) "Idées obsédantes" propriamente ditas — as obsessões intelectuais dos franceses, "Grübelsucht" de Griesinger e Berger. O paciente não consegue escapar da obsessão de pensar sobre determinado assunto ou questão. Não se trata de uma questão de percepção ou emoção, nem de um impulso para cometer um ato; há apenas uma ideia isolada - uma palavra, uma frase — que persegue o paciente sem cessar e continuamente ocupa seus pensamentos.

Van Eeeden vê naquilo que chama de "manias de superstição" uma interessante variedade das obsessões. Um de seus pacientes, um homem de quarenta anos, de constituição saudável, atribui significado profético a fatos e eventos triviais desde a infância. Usar certa gravata lhe promete felicidade ou infelicidade. Se não tocar em certa borda, ele acredita que algo de ruim vá lhe acontecer. Se não reler certa linha ou não fizer certa letra mais grossa ao escrever algo, algo terrível lhe sucederá. Inicialmente suas estranhas ideias eram insignificantes, ou ele era capaz de resistir a elas, mas com o passar dos anos elas vieram a ocupar toda sua vida, tornando-a intolerável. Durante vinte anos ele fez uma peregrinação todos os domingos à estação de trem para chutar certo poste três vezes com cada pé. Se não fizesse isso, seu pai morreria. A fim de livrar-se dessas obsessões, ele faz votos e associa ameaças a elas. Ele fala, por exemplo: "Se eu ceder a um de meus caprichos no decorrer de uma hora terei apoplexia antes que 24 horas se passem". No início isso funcionou, mas o efeito dos votos logo diminuiu e ele sentiu-se compelido a torná-los ainda mais fortes. O infeliz homem agora chega a ficar 15 minutos resmungando as mais terríveis imprecações procurando desta forma reunir forças para executar pequenas tarefas. Se ele as omite, é forçado a obedecer aos impulsos mais absurdos. Ele deve parar diante de certa casa, refazer seus passos, tocar bordas, parar transeuntes ou tocar suas roupas; em uma palavra, ele é obrigado a agir como um maníaco. Seu intelecto é perfeitamente normal e ele realiza seu trabalho como se não tivesse problema algum.

Bérillon acredita que o caráter profissional destes distúrbios nervosos não foi suficientemente notado e faz uma analogia entre estes e os diferentes espasmos funcionais que mostram uma tendência à localização profissional. A título de ilustração, ele cita os seguintes casos: um jovem sacerdote, que não se mostrava tímido durante a realização de seus outros deveres religiosos, sofria de agonia ao subir ao púlpito. Outro sofria da mesma maneira ao receber uma confissão. Um estudante de medicina 


\section{CLÁSSICOS DA PSICOPATOLOGIA}

sofria de extrema agonia perante a visão de algumas gotas de sangue. Um farmacêutico fez a manipulação de um medicamento prescrito em uma receita médica que causou a morte de um cliente. Ele conseguiu provar que a receita fora preparada exatamente conforme as ordens do médico, mas como sua existência tornou-se uma verdadeira tortura devido ao medo constante de cometer um erro, ele vendeu seu negócio. Um tabelião era acometido por medos mórbidos somente quando solicitado a dar uma opinião profissional. Um barbeiro reparou um dia que suas mãos tremiam e a partir daí passou a ter o constante temor de que o tremor voltaria quando estivesse barbeando seus melhores clientes. Ele não sentia a mesma ansiedade quando barbeava um homem pobre ou um cliente desconhecido. O Dr. Frémineau relata o caso de um ator que abandonou a profissão devido ao medo extremo do palco. Esta condição surgiu apenas depois de uma carreira de sucesso. O Dr. Bérillon relata diversos casos similares. Riegler observou um medo mórbido entre mecânicos ferroviários ao qual ele deu o nome de "sidérodromophobie", caracterizado por uma aversão extraordinária à ocupação habitual e a pela ansiedade perante a visão de um trem ou o som de um apito de motor. Grasset menciona que um distinto cirurgião parisiense começa a sentir-se ansioso assim que o paciente deixa seu consultório com uma prescrição. Ele pergunta-se ansiosamente se pode ter escrito centigramas em vez de miligramas e somente recobra sua calma mental quando seu empregado, enviado para procurar o paciente, retorna com a receita e ele pode ver que está tudo certo. Outro médico, conta Grasset, ficou totalmente infeliz devido ao medo de micróbios. Brochin relata o caso de um médico que não tem medo de nenhuma doença contagiosa, exceto a difteria, e que dá provas de verdadeiro heroísmo a cada vez que recebe um paciente com a doença. Recentemente foi relatado um caso vindo do exterior no qual um médico, por medo de que seus honorários pudessem ser um meio de contágio, inventou elaborados métodos de esterilizá-los, e eu sei de um caso similar neste país.

Estes medos mórbidos são estranhos o suficiente quando ocorrem na vida ordinária, mas, segundo Bérillon, adquirem mais grave importância quando os sujeitos a ele são pessoas mais propensas ao serviço militar, especialmente nas filas. No caso clássico de agorafobia de Legrand du Saulle, um tenente da infantaria foi tomado de indefinível agonia quando obrigado a cruzar um espaço aberto em trajes civis, o que nunca ocorrera quando usava o uniforme. Quando um policial sofre desta forma, ele pode escapar à situação intolerável obtendo uma licença, enquanto o soldado não pode fazer o mesmo. Bérillon fornece os seguintes exemplos, entre outros:

Paul C., 25 anos, sua doença data da época do serviço militar. Ao ser ordenado a cruzar a barra horizontal no ginásio, ele foi tomado de extrema apreensão e depois disso a ideia do exercício permaneceu sempre presente. Uma vez mais ordenado a fazê-lo, ficou apavorado e pediu para ser dispensado, mas a partir deste momento seus superiores insistiram cada vez mais no temido exercício. Um dia, ao tentar cruzar a 
barra, ele ficou tonto e caiu sobre a cabeça. Uma verdadeira agorafobia se desenvolveu e desde seu retorno do serviço militar é incapaz de atravessar a rua sozinho.

M., 37 anos, sofria de diarreia crônica, o que o levou a ter medo de sair de casa. A diarreia cessou, mas seus medos nervosos permaneceram. Uma vez, quando estava a curta distância de casa, a ansiedade foi tão forte que ele foi obrigado a retornar e desde então, há sete anos, reside em um círculo de cerca de 200 metros de diâmetro, e nada o convence a deixá-lo. Quando foi membro da reserva e precisou servir seu primeiro período de 28 dias, conseguiu fazê-lo, mas no segundo período a agorafobia havia se desenvolvido e por força de diplomacia, engenhosidade e suborno, conseguiu ser mantido constantemente empregado dentro do quartel.

Segundo o Dr. Gelineau, muitos sentimentos de repugnância e similares, agrupados pelos leigos como aversões, se assemelham às condições que estamos discutindo. Henrique III, por exemplo, que demonstrou sua bravura no Cerco de La Rochelle e em outros sítios, não suportava olhar para os gatos. O duque de Epernon desmaiou ao ver um pequeno jumento. Ladislas, Rei da Polônia, assustou-se e fugiu ao ver maçãs e Favoriti, um poeta moderno italiano, não suportava o cheiro das rosas. O Dr. Pierre d'Apono sentia tanto medo ao ver leite e queijo que desmaiava. Montaigne afirma: "Eu já vi mais pessoas fugindo do cheiro das maçãs que dos arcabuzes, já vi outras assustadas por um rato, doentes perante a visão de creme de leite ou de um colchão de penas sendo sacudido".

Ribot aplica o termo "ideias fixas" aos estados que estamos discutindo e considera-os "hipertrofia crônica da atenção", sendo as ideias fixas absolutas, e a atenção a predominância temporária de um estado intelectual ou grupo de estados. A ideia fixa é atenção em seu grau mais elevado e marca o limite extremo de seu poder de inibição. Há, ele afirma, tanto na atenção normal quanto nas ideias fixas, predominância e intensidade de um estado de consciência; isso é, porém, mais marcado na ideia fixa, que é permanente, e dispõe do importante fator psíquico — tempo. "Na atenção este estado excepcional não dura muito, a consciência reverte-se espontaneamente a seu estado normal, que é uma luta pela existência entre estados heterogêneos. A ideia fixa impede qualquer difusão. Não há estado antagônico capaz de derrubá-la. O esforço é impossível ou vão. Daí a agonia do paciente, consciente de sua própria impotência”. Eis a concepção de Ribot a propósito da provável condição fisiológica associada às ideias fixas: "Em seu estado normal, todo o cérebro funciona; atividade difusa é a regra. A descarga se dá de um grupo de células para outro, o que é o equivalente objetivo da perpétua alteração de consciência. No estado mórbido, apenas poucos elementos nervosos estão ativos ou, pelo menos, seu estado de tensão não é transmitido aos outros grupos. Seja qual for sua posição no órgão cerebral, eles estão, na realidade, isolados; toda energia disponível acumulou-se neles, e eles não a comunicam para outros grupos, de onde seu domínio supremo e sua exagerada atividade. Há uma falta de equilíbrio fisiológico devida, provavelmente, ao estado de nutrição dos centros 


\section{CLÁSSICOS DA PSICOPATOLOGIA}

cerebrais". Ribot faz referência ao reconhecimento por parte de Westphal da diferença entre ideias fixas e alienação e à sua afirmação de que "a ideia fixa é uma alteração formal do processo de ideação, mas não de seu conteúdo". A perturbação formal, segundo Ribot, consiste na necessidade inexorável que compele a associação a sempre seguir o mesmo caminho. "Há alteração, não na natureza, na qualidade da ideia, que é normal, mas em sua quantidade, intensidade e grau". Assim, é perfeitamente racional refletir sobre a utilidade das notas de dinheiro, ou sobre a origem das coisas, e esse estado difere muito daquele do mendigo que pensa ser um milionário, ou do homem que acredita ser uma mulher.

\section{Tratamento}

Os seguintes casos, de minha própria prática e de outros, ilustram o valor da sugestão hipnótica nos casos de "ideias imperativas".

(1) O Senhor A., 24 anos, consultou-me em maio de 1889. Alguns meses antes, ele removera glândulas doentes da face e do pescoço, e partiu para o Mediterrâneo para recrutar-se. Ao cruzar uma prancha, ele caiu e machucou o períneo; formou-se um abscesso, que explodiu externamente e para dentro da uretra. Quando eu o vi, havia uma grande ferida insalubre, através da qual a urina escapava. Instruí-o a utilizar regularmente um catéter macio e a ferida começou a melhorar. Um dia, ele foi impelido a esvaziar a bexiga antes de conseguir usar o instrumento e o líquido escapou pela ferida novamente. Isso aconteceu com cada vez mais frequência, até que a ideia de urinar de uma vez só fazia-o esvaziar a bexiga, onde quer que estivesse. Isso parecia ser totalmente independente da condição física da bexiga, que não contraía porque estava cheia ou desconfortável, mas porque a ideia de urinar se apresentava à mente do paciente e era imediatamente traduzida em seu equivalente físico. Agora ele pensava constantemente sobre sua condição que, em consequência, agravou-se bastante. Ele passou a dormir mal e acordar frequentemente durante a noite; no instante em que o fazia, pensava em sua bexiga e era imediatamente compelido a esvaziá-la. Apesar do tratamento, isso continuou durante vários meses e seu estado tornou-se grave. Eu não havia previamente empregado o hipnotismo, mas o elemento mental neste caso parecia tão relevante que me decidi, uma vez que os demais tratamentos haviam falhado, a tentar e ver o que sucederia. Depois de explicar ao meu paciente, um homem culto, que eu não tinha nenhuma prática, e apenas um pequeno conhecimento teórico sobre o assunto, eu procedi a hipnotizá-lo pelo método de Brad. Em poucos minutos, seus olhos rolaram para cima e para dentro e ele se tornou letárgico. Repeti isso nos dois dias que se seguiram, e sugeri, durante a hipnose, que ele deveria parar de pensar sobre 
sua bexiga, deveria sempre usar o catéter, reter sua urina por oito horas e dormir bem. Essas sugestões foram imediatamente cumpridas; a partir desse dia, seus incômodos sintomas não retornaram e a ferida curou sem operação em cerca de 12 meses.

(2) O Sr. B., 25 anos, consultou-me pela primeira vez em março de 1890. Já fora forte e atlético, destacado jogador de futebol, ciclista etc. Dois anos antes, após sua mãe ter falecido de câncer na mama, ele começou a ter medo de contrair a mesma doença. A ideia tornou-se cada vez mais forte, ele desenvolveu sintomas neurastênicos e sofria de insônia, depressão, dispepsia etc. Por fim, o pavor do câncer passou à firme convicção de que sua mama esquerda estava infectada. Ele agora permanecia quase sempre em um quarto e não passava para outro sem se cobrir e vestir um sobretudo. Por alguns meses reclamou de dificuldade em mover o braço esquerdo e mantinha-o em uma tipoia. Não encontrei nada que justificasse seus temores, mas os músculos dos braços estavam distintamente atrofiados por falta de uso. Ele foi facilmente hipnotizado na primeira tentativa, e isso se repetiu diariamente durante 15 dias, quando foi obtida a hipnose profunda com sonambulismo. Suas ideias mórbidas desapareceram de uma vez e seu estado geral de saúde melhorou rapidamente. Alguns dias após o fim do tratamento, eu o vi montando um vigoroso cavalo e segurando as rédeas com a mão esquerda. Uma semana depois, ele me disse que sentia-se perfeitamente bem e se preparava para saltar obstáculos com um jovem cavalo. Até a presente data não houve recaída.

(3) O Sr. C., 30 anos, consultou-me em julho de 1890. Gozava de boa saúde até seis meses antes, quando ficou com medo por ter sido acordado por sua irmã, que tinha mania aguda, entrando em seu quarto. A partir dessa data, passou a sofrer de insônia e dispepsia, perdeu peso e vigor, tornou-se melancólico, evitava a sociedade e tinha a ideia fixa de que se tornaria louco. Foi hipnotizado cinco vezes, de 3 a 7 de julho de 1890. A hipnose profunda foi facilmente induzida na primeira tentativa, e ele dormiu bem em todas as noites. Recuperado. Sem recaídas até maio de 1891, quando morreu de influenza.

(4) O Sr. D., 43 anos, consultou-me pela primeira vez em setembro de 1892. Sua doença teve início na primeira infância, com a ideia fixa de que todo mundo o observava e criticava, e começou a enrubescer quando era olhado. Não apenas enrubescia de maneira excessiva quando alguém, até mesmo seus próprios filhos, olhava para ele, mas o pensamento de que qualquer pessoa pudesse olhá-lo era suficiente para fazê-lo corar, mesmo se estivesse sozinho. Sentia que devia deixar os negócios e tinha pensamentos suicidas. Sofria de diversos sintomas neurastênicos. Tentei hipnotizá-lo por cinco vezes sem resultados. Ele retornou ao tratamento em abril de 1893. Seu estado piorara e ele estava desesperado. Hipnotizei-o 42 vezes até outubro de 1893. Ligeira 


\section{CLÁSSICOS DA PSICOPATOLOGIA}

hipnose foi induzida na quinquagésima tentativa e a partir daí tornou-se bastante profunda; ele começou a melhorar e antes do final do tratamento seus sintomas mórbidos haviam desaparecido. Notícias recentes confirmam sua recuperação.

(5) Sra. E., 36 anos. Culta e muito inteligente. Um de seus irmãos possui uma deficiência intelectual congênita e ela sofre de crises de depressão desde a infância, que se tornaram mais frequentes e prolongadas nos últimos 14 anos. A condição mental de um de seus filhos, nascido durante um desses períodos, provoca grave ansiedade, e outra criança mais nova gagueja. Há quatro anos e meio, após a morte de um parente que exercera uma influência hostil em sua vida, ela pensava constantemente que as diversas desgraças que estavam lhe acontecendo dariam prazer a esse parente; a ideia cresceu e desenvolveu-se, até que ela passou a sentir que ele sabia tudo o que ela fazia e regozijava-se com seus problemas. Finalmente, ela ficou possuída pela ideia de que era possuída por ele e sentia consciência de sua presença. Toda sua vida ficou preenchida por esses pensamentos e ela deixou de se importar com a sociedade ou com conquistas intelectuais. Estava constantemente deprimida, dormia mal e encontrava-se fisicamente fraca. Tentei hipnotizá-la pela primeira vez em 26 de novembro de 1892, e repeti a tentativa uma centena de vezes sem sucesso, até o dia 25 de abril de 1893. Sua condição nesse período ficou cada vez pior. Hipnose leve foi induzida no dia 26 de abril e repetidas 23 vezes até 21 de julho de 1893. Imediatamente após a primeira indução de hipnose, ela melhorou rapidamente e as ideias mórbidas e a depressão desapareceram completamente. Ela rapidamente recuperou a força e o interesse pela vida e até a presente data não houve nenhuma recaída.

(6) Sra. F. Recebi do Dr. F, marido da paciente, as seguintes notas sobre este caso: "Minha esposa teve mixedema, seguido de gripe; ela apresentou temperatura baixa, perda de cabelo, enfraquecimento intelectual, lentidão de movimento, inchaço geral irregular no corpo, desfiguração facial, alteração de voz e dores musculares. Tratei-a com extrato de tireoide em janeiro de 1893, e embora os sintomas peculiares ao mixedema tenham desaparecido, ela ficou completamente insone, seus membros passaram a tremer após o menor esforço e sua digestão tornou-se muito ruim. Eu a trouxe a você no dia $1^{\circ}$ de março de 1894 para ver se ela conseguiria dormir através da sugestão. Na segunda tentativa você conseguiu induzir ligeira hipnose e ela passou a dormir moderadamente bem. Durante mais de um ano ela não tivera mais que três horas de sono quebrado, e com frequência muito menos. Logo começou a dormir muito bem e ininterruptamente e sua digestão, para a qual medicamentos e uma dieta cuidadosa haviam sido ineficazes, melhorou depois de poucas sugestões. Suas pernas tornaram-se fortes e sua energia foi restaurada, como haviam sido vinte anos atrás, quando ela era reputada entre seus conhecidos por sua incansável atividade. Mas o fato que me causa a mais forte impressão é o que segue. Diversos membros de sua família 
são sonâmbulos. Ela costumava andar dormindo durante a infância, o que se repetiu uma ou duas vezes quando era jovem, e o hábito foi transmitido à minha filha mais nova. Quando seu primeiro filho nasceu, há 16 anos, o pensamento passou pela mente de minha esposa: 'E se eu andar dormindo e machucar o meu filho? 'Esforcei-me para convencê-la que, ao crescer, ela havia deixado o hábito para trás, mas a tentativa foi completamente infrutífera. A ideia cresceu até assumir o caráter de uma ideia fixa, e ela sempre se amarrava ao pé da cama durante a noite. Todas as tentativas de tirá-la desse hábito falharam e, se fosse para a cama sem se prender, nunca conseguia dormir até tê-lo feito. Quando nos mudamos para nossa residência atual, há três anos e meio, ela ficou alarmada com a altura elevada das janelas do quarto, e com o fato de serem muito próximas do chão. Ela passou a sugerir que havia a possibilidade de desamarrar os nós durante o sono e sair pela janela. Assinalei quão improvável era que ela viesse a andar dormindo após tantos anos de completa imunidade. Ela admitiu a lógica em meu raciocínio, mas isso não dissipou seu medo, e ela insistiu que eu a amarrasse à cama todas as noites de modo bastante eficaz. Em maio de 1894, contei a você deste medo persistente e fiz o pedido de que lhe sugerisse que não deveria andar durante o sono e nem ficar apreensiva de fazê-lo. Durante essa sessão, você repetiu essa sugestão duas ou três vezes, mas não o fez desde então. O efeito foi mágico. Desde aquele dia ela nunca me pediu para amarrá-la à cama e me diz que nunca mais pensou sobre isso. Para mim é tanto mais notável que a hipnose em seu caso seja tão leve e pareça passar para o sono natural se ela for deixada por alguns segundos. Ela possui um temperamento nervoso e excitável, mas de maneira alguma é ávida pelo fantástico ou pronta a acreditar em qualquer doutrina. Ela possuía um ceticismo saudável quanto à possibilidade de alguém hipnotizá-la, mas estava ansiosa para que a tentativa fosse feita, uma vez que sofria tão intensamente."

Eu vi a paciente 12 meses depois, quando ela me contou que estava totalmente livre de seus medos mórbidos.

(7) O Sr. G, 28 anos, consultou-me pela primeira vez em abril de 1894. Seu pai era muito nervoso e passional, e sofrera de "febre cerebral" e coreia. O paciente é frágil e de baixa estatura, e sofre de diversos sintomas neurastênicos. Aos 14 anos, possuía muitos medos e dúvidas religiosas, e acreditava haver cometido um pecado imperdoável. Aos 16, quando trabalhava em uma fábrica de cacau, começou a ter medo que o chumbo vermelho, utilizado na fixação de certos tubos de calor, poderia entrar nas latas de cacau, envenenando pessoas. Este foi o início da "folie du doute" e do "délire de toucher", que nunca mais o deixaram desde então. Em vez de fazer seu trabalho, ele era irresistivelmente impelido a limpar e relimpar as latas. $\mathrm{O}$ excerto seguinte provém de uma carta de um amigo a quem ele confiou seus problemas: "Em $1^{\circ}$ de outubro de 1891, disse-me que havia tentado cometer suicídio, já que sua vida era tão infeliz (ele ingeriu veneno). Ele lera um caso de envenenamento por ingestão 


\section{CLÁSSICOS DA PSICOPATOLOGIA}

de chocolate e conectou a si mesmo com o caso, embora já houvesse passado cinco anos desde que ajudara a manufaturar o produto. Ele agora acreditava que havia sido negligente com os moldes e, portanto, produzido chocolate envenenado que anos depois causaram a morte da criança! O absurdo grotesco da história, conforme ele me relatou, teria me feito rir se eu não tivesse sentido o quão terrivelmente real isso era para ele. Sua imaginação vívida havia visualizado todos os incidentes da tragédia; a criança comprando o chocolate, correndo para casa cheia de felicidade, caindo doente e, gradualmente, adoecendo em terrível agonia até ser libertada pela morte. A agudeza da mente com a qual ele procurava provar a razoabilidade da crença de que envenenara a criança era extraordinária. Ele escreveu: 'Ontem eu estava desparafusando algumas bocas a gás em uma mercearia e fiquei com um pouco de chumbo branco em minhas mãos, então pensei que ele provavelmente havia caído no meio da comida'. Notei que remoer essa fantasia havia-o deixado à beira do desespero e durante semanas sua vida foi uma perpétua agonia. Ele está preocupando-se com seu trabalho de fixar painéis de propaganda nas paredes e nunca consegue persuadir-se de que estão seguramente fixados. Imagina que os pregos são ruins, ou que a argamassa está solta, e faz a si mesmo doente ao pensar sobre isso. Observei que se uma placa caísse, quase inevitavelmente deslizaria pela parede. Isso não o impediu de pintar um quadro mental bastante elaborado de uma infeliz criança que naquele momento estaria brincando de bolinhas de gude com sua cabeça contra a parede. Para enumerar todos os seus problemas seria necessário um pequeno volume. Tenho uma grande pilha de suas cartas na minha frente agora, e suponho que elas constituam uma das mais extraordinárias autobiografias analítica possíveis de se encontrar. Ao lê-las não posso deixar de admirar-me perante o caráter estranhamente fantástico de tal imaginação. Ele faz de todo incidente de sua vida a pedra fundamental de um castelo de fantasias, e nos últimos anos cada castelo se tornou uma prisão - uma câmara de tortura na qual ele disseca seus motivos até ter deixado totalmente de acreditar em si mesmo".

Quando atendi esse paciente pela primeira vez, a "folie du doute" e o "délire de toucher" eram constantes e variavam bastante em suas manifestações. Se ele acidentalmente tocasse pessoas na rua, passava a ter medo que poderia tê-las machucado e exagerava o toque em um empurrão mais ou menos violento. Se a pessoa tocada fosse uma mulher, ele temia que ela estivesse grávida e que ele pudesse ter ferido a criança. Se visse um pedaço de casca de laranja na calçada, chutava-o para a rua, mas logo em seguida começava a pensar que ali seria um local mais perigoso, já que qualquer pessoa que escorregasse nele poderia bater a cabeça contra o meio-fio, de modo que era irresistivelmente impelido a retornar e colocá-la de volta em sua posição anterior. Houve um tempo em que costumava comprometer-se a realizar certos atos, jurando dar a Deus seu dinheiro caso não o fizesse. A seguir, às vezes tinha dúvidas se havia jurado ou não. Devido a isso pagou quantias em objetos religiosos que eram bastante desproporcionais à sua renda. À parte suas peculiares fantasias, achei o paciente 
perfeitamente racional e inteligente e embora seu "délire $d u$ toucher" o atrapalhasse enormemente em seu trabalho, ele geralmente conseguia executá-lo, apesar de em algumas ocasiões sentir-se compelido a desistir. Nesse momento tentei hipnotizá-lo em 24 ocasiões, mas aparentemente sem sucesso, e ele foi compelido a sair da cidade. Retornou no dia 2 de abril de 1895 para uma semana de tratamento adicional e disse-me que desde sua última visita suas ideias mórbidas não haviam sido tão frequentes e destacadas e eram acompanhadas de menos agonia mental. Sua condição, todavia, deixa muito a desejar.

(8) O Sr. H., 33 anos, alto, forte e atlético, consultou-me pela primeira vez em 7 de março de 1894. Afirmou ter sido sempre de disposição sensível e inclinado a ser morbidamente autoconsciente. Nos últimos anos, isso se desenvolvera muito, tornando sua vida um fardo. Tinha a ideia fixa de que estava constantemente cometendo erros nos negócios e que todos que tinham contato com ele o consideravam um tolo. Durante uma entrevista de trabalho ficava envergonhado e incapaz de falar e sentia que todo mundo notava. Tinha as mesmas sensações em relação à sociedade e evitava-a tanto quanto possível. Possuía ainda medos mórbidos e completamente infundados sobre sua condição física. Foi hipnotizado dez vezes até 11 de julho de 1894, quando suas ideias mórbidas desapareceram totalmente. Acaba de se declarar bem de saúde, em abril de 1895. Se sente quaisquer ansiedades sobre seu trabalho, diz ele, trata-se apenas de ansiedades naturais e perdeu todos seus medos e constrangimentos mórbidos. É agora apreciador da sociedade e sente-se à vontade nela.

(9) Sr. I., 35 anos, foi enviado a mim pelo Dr. de Waterville em 29 de outubro de 1894. A doença começara seis meses antes, após a morte repentina de seu cunhado. Ele passou a dormir mal e a sonhar com sua própria morte. A insônia continuou e ele era assombrado por temores constantes referentes a ele mesmo e à sua família. Temia que perderia seu emprego e que encontraria sua esposa e seus filhos mortos quando retornasse do trabalho. Passou a ter medo de espaços abertos e era incapaz de atravessar a rua sem ajuda. Um dia, sentado sozinho em sua sala de estar, acreditou ter visto dois homens trazendo seu caixão para dentro. Não tinha nem um momento livre de seus medos, e estava tão infeliz que possuía fortes impulsos suicidas. Por volta dessa época, passou a ter frequentes ataques de tontura e sentia que cairia caso não se segurasse em alguma coisa. Em apenas uma ocasião perdeu a consciência. Foi hipnotizado cinco vezes até o dia 12 de novembro, data em que seus medos mórbidos haviam quase completamente desaparecido, mas como ele ainda tinha ataques de tontura e às vezes sentia-se deprimido, continuei a hipnotizá-lo uma ou duas vezes por semana até a presente data (26 de abril de 1895). Condição atual: dorme bem e não tem ataques de tontura há dois meses, não tem agorafobia, seus medos mórbidos não retornaram e a hipnose profunda pode agora ser fácil e rapidamente induzida. 


\section{CLÁSSICOS DA PSICOPATOLOGIA}

(10) Sr. Watts. Fui solicitado pelo Dr. Hack Tuke a tentar hipnotizar esse paciente, número dez em sua lista de casos. Nesse momento ele estava há 12 meses no Hospital Bethlem e às vésperas de receber alta, já que sua condição mental mantinha-se inalterada $\mathrm{e}$ fora considerado desaconselhável retê-lo por mais tempo. O Dr. Percy Smith gentilmente consentiu em mantê-lo por mais um mês para o propósito desta experiência e eu tentei hipnotizá-lo 23 vezes sem sucesso. Recentemente encontrei-o acidentalmente. Ele me disse que sua condição permanecia inalterada e que estava indo viver em uma fazenda.

O Dr. Hack Tuke também me pediu para tentar hipnotizar seu paciente número 11. Quando vi o paciente, ele era evidentemente alienado e extremamente desconfiado e nada poderia induzi-lo a submeter-se ao tratamento.

(11) (Liébeault) Senhora , maio de 1892, 36 anos. Gozou de boa saúde até o início da doença atual há 11 meses. Seu pai cometeu suicídio por afogamento; seu primeiro marido afogou-se acidentalmente 12 dias após o casamento e ela perdeu seu segundo marido repentinamente após três anos de casados. Desde então evita os amigos, dorme mal, negligencia seu trabalho e a si mesma e possui a ideia fixa de que deveria cometer suicídio afogando-se como seu pai o fez. Em uma carta recente o Dr. Liébeault afirmou que ela está bem mental e fisicamente.

(12) (Schrenck-Notzing). Senhor . A ideia fixa de pegar um resfriado manteve esse paciente em seu quarto por seis meses. Hipnotizado. Recuperado.

(13) (Schrenck-Notzing). Senhor , 24 anos. Teve períodos de terror e sensações incontroláveis com a ideia fixa de que sua noiva não o amava. Hipnotizado. Recuperado.

(14) (Hecker). Senhora Sofria do desejo doentio de lavar-se contínua e desnecessariamente; possuía medos mórbidos de que as portas e janelas não estavam adequadamente fechadas e fantasiava que suas roupas estavam desarrumadas. Em uma ocasião, depois de ter passado duas horas tentando em vão se vestir, ela pediu a Hecker que viesse vê-la. Ele encontrou-a em um estado de grande ansiedade, colocando e tirando as roupas até a exaustão. Hipnotizada por um mês. Recuperada.

(15) (Wetterstrand). Senhora , 42 anos. Durante anos possuía um pavor mórbido de trovoadas; não tinha coragem de ir para o campo no verão e no inverno temia o que traria o verão. Observava constantemente a aparência do céu. Hipnotizada vinte vezes. Recuperada.

(16) (De Jong). Senhor . Agorafobia com duração de muitos anos. Hipnotizado dez vezes. Recuperado. Nenhuma recaída depois de um ano e meio. 
(17) (De Jong). Senhora . Medo de tempestades e de viajar de trem. Hipnotizada. Recuperada.

(18) (Van Eeden e Van Renterghem). Senhor. , 56 anos. Impotência psíquica por três anos com a ideia fixa, a qual ele reconhecia ser falsa, de que sua esposa desejava ser infiel a ele. Hipnotizado oito vezes. Recuperado. Nenhuma recaída depois de 22 meses.

Esta lista pode ser amplamente estendida. Muitos dos casos referidos no início do artigo foram tratados com êxito por sugestão hipnótica e muitos outros foram reportados por Bernheim, Delbceuf, Gorodichze, Russell Sturgis, Voisin, Burot, Mavroukakis, Bourdon etc.

Minha principal dificuldade nesses casos é a indução da hipnose primária. Diversas estatísticas continentais aparentemente mostram que a maior parte da humanidade pode ser hipnotizada; a "Primeira Estatística Internacional sobre Suscetibilidade Hipnótica", artigo de Schrenck-Notzing publicado em 1893, traz 8.705 casos de 15 observadores em diferentes países com $6 \%$ de falhas. Wetterstrand reporta 105 não influenciados entre 6.500 casos e em minha própria prática encontrei pacientes igualmente suscetíveis.

Para a indução da hipnose a atenção do paciente é necessária e em casos de ideias imperativas a atenção encontra-se ocupada como resultado na natureza da afecção mental. Muitas pessoas pertencem também à classe mais difícil de influenciar, isto é, a nervosa e emocional. Que tais pacientes são os mais fáceis de hipnotizar é a convicção de todos aqueles que não possuem conhecimento prático do assunto; mas essa opinião, infelizmente, não está baseada em fatos. Moll afirma: "Os mentalmente instáveis, particularmente idiotas, são muito mais difíceis de hipnotizar do que as pessoas saudáveis. Pessoas inteligentes e aquelas de vontade forte são mais facilmente hipnotizáveis do que as estúpidas e de vontade fraca. Sexo não tem influência em particular". Segundo Forel, “todo homem mentalmente saudável é naturalmente hipnotizável”. O Sr. Wingfield hipnotizou 152 alunos de Cambridge na primeira tentativa, enquanto Esdale não encontrou nenhuma dificuldade em induzir a anestesia hipnótica nos cules e criminosos de Bengala os quais, como ele observou com justeza, não são pessoas nervosas sob nenhum aspecto. $\mathrm{O}$ fato de que muitos de meus pacientes haviam lido artigos em jornais e revistas sensacionalistas sobre o tema não tornou minha tarefa mais fácil.

$\mathrm{Eu}$, pessoalmente, nunca vi o mais leve sintoma desagradável resultar do uso hábil da hipnose, nem qualquer evidência de que seus perigos, sob essas circunstâncias, tenham qualquer existência a não ser no cérebro do romancista. Forel afirma: "Liebeault, Bernheim, Wetterstrand, van Eeden, de Jong, eu mesmo e outros seguidores da escola de Nancy declaramos categoricamente que nós, apoiados pelo material de milhares de pessoas hipnotizadas, jamais observamos um único caso de dano mental 


\section{CLÁSSICOS DA PSICOPATOLOGIA}

ou corporal causados pela hipnose, mas, ao contrário, vimos diversos casos de doenças aliviados ou curados por ela".

No que diz respeito à ligação entre a "folie du doute" e o "délire de toucher", é interessante notar que este ocorreu no caso número sete assim que as dúvidas do paciente tomaram uma forma material, mas não estavam associadas quando suas obsessões eram puramente intelectuais. Não mostraria isso que o aparecimento do "délire du toucher" simplesmente depende da natureza da "folie du doute" e que as lavagens incessantes e seus similares são os esforços físicos naturais do paciente para livrar-se de seus medos materiais, enquanto o caráter das obsessões puramente intelectuais torna tal alívio impossível? G procurou e encontrou seu equivalente mais próximo na narração de seus problemas religiosos a um amigo mais velho, em cujas opiniões ele tentou encontrar consolo. Desse ponto de vista, o segundo dos casos citados por Ladame mostra a "folie du doute" desassociada do "délire du toucher". Essa separação é, penso eu, mais artificial do que real. Em seu primeiro caso, aquele do jovem que lavava suas mãos com frequência devido ao medo de contaminação, não está de modo algum claro que se tratava de "délire de toucher" sem "folie du doute". Certamente as abluções anormais e incessantes devem ter sido o resultado de dúvidas que ele tentou resolver dessa forma. As mesmas objeções poderiam ser levantadas nos casos de van Eeden em que a "folie du doute" é tida como resultado do "délire du toucher".

O Dr. Hack Tuke vê as ideias imperativas, e os atos dela resultantes, como essencialmente automáticos, considerando esta sua característica fundamental. Serão esses atos automáticos? Um ato automático é simplesmente um ato habitual voluntário realizado distraída ou inconscientemente, enquanto os assim chamados atos automáticos daqueles que sofrem de ideias imperativas são levados a termo em oposição à sua vontade e frequentemente associados à intensa e dolorosa consciência. Possivelmente eles poderiam ser chamados com justeza de reflexos, uma vez que são "respostas fatais e não escolhidas à estimulação".

$\mathrm{O}$ fato de uma ideia imperativa permanecer estranha ao ego do paciente distingue-a, de acordo com a maior parte das autoridades, de um delírio de alienação. Essa regra tem suas exceções. Um de meus pacientes começou a ser "inibido" por superstições dez anos atrás. No início, isso ocorria raramente, mas, ultimamente, devido a um excesso de dias azarados e afins, a realização de muitos atos está comprometida. Muitas pessoas, de modo algum alienadas, acreditam de fato e são influenciadas por idênticas superstições. Este paciente, entretanto, não acredita nelas, e ressente-se agudamente de sua interferência em suas ações. Assim, a não assimilação da ideia imperativa às vezes constitui o elemento mórbido e isso aparentemente depende mais do indivíduo do que da ideia em si. A paciente que se debruçou sobre a Criação a ponto de se tornar infeliz poderia, em outro momento e circunstância, sentir prazer em discutir "quantos anjos podem ficar em pé na ponta de uma agulha ou se, ao passar de uma ponta a outra, seria preciso atravessar o espaço intermediário". A ideia imperativa de descobrir 
o local da antiga Troia apenas difere daquelas que estamos discutindo pelo fato de ser sido assimilada por seu possessor, mas não constituiu alienação.

Em quase todos os meus casos a condição parece ter tido uma origem emocional. $\mathrm{O}$ choque da súbita morte de um parente fez com que um paciente temesse que sua esposa morresse, e outro tinha medo de viajar depois de ter sido assustado por um homem embriagado em um vagão de trem. Embora em alguns casos o elemento emocional tenha mudado seu caráter, tornando-se imensamente intensificado como um todo, ele certamente foi com frequência associado ao início do problema original.

Ideias imperativas são geralmente vistas como típicas da degeneração e especialmente da degeneração hereditária. Alguns de meus casos parecem confirmar isso — os pacientes eram mental e fisicamente frágeis e possuíam antecedentes hereditários insatisfatórios. Em diversos exemplos as ideias imperativas haviam se tornado delírios de alienação, muitos pacientes tinham impulsos suicidas, um deles tentou o suicídio e outro tinha alucinações. Por outro lado, a transição do estado normal para as ideias imperativas é quase insensata, sendo a repetição de um dito insignificante, segundo Ribot, a forma mais leve, e a preocupação, como a ansiedade antes de uma prova, um grau acima dela. A maioria das crianças também sofreu, em um momento ou outro, de ideias imperativas. Isso, como um escritor popular observou recentemente, parece advir de um sentimento exagerado de importância daquilo que dizem e fazem em relação a serem notados pelos outros. Ele afirma: "Quão infelizes nos fazemos a nós mesmos devido a algum comentário bobo que fizemos. Alguns de nós mantemos um pequeno estoque das coisas tolas que fizemos ou dissemos em vários momentos, tirando-as para fora ocasionalmente e nos envergonhando delas. Quando criança, envergonhei-me durante anos por ter dado uma resposta na Igreja no local errado, antes de ter terminado a vez do clérigo. Senti que toda a congregação havia se virado e me olhado com desprezo, ridicularizando-me. Enquanto eu andava, cada pessoa que me olhava eu estava certo de que pensava: 'lá vai a criança que deu aquele extraordinário grito na Igreja."”

Nem todos podem ter ideias fixas, como, por exemplo, os idiotas, que possuem pouca atenção espontânea e nenhuma atenção voluntária, enquanto, conforme afirma Ribot: "Em qualquer ser humano saudável há sempre uma ideia dominante que regula sua conduta, como o prazer, dinheiro, ambição ou a salvação de sua alma". Vários de meus pacientes estavam fisicamente muito acima da média, muitos deles possuíam dotes mentais de alta qualidade e suas ideias mórbidas não o impediam de fazer um trabalho valioso. A maior parte deles, é verdade, eram de tipo nervoso e emotivo, mas um cérebro móvel e sensível é necessariamente degenerado? Não podem os acidentes aos quais estão suscetíveis serem o resultado de seu desenvolvimento maior e mais complexo? O puro-sangue é mais emotivo e nervoso do que o cavalo de carroça, mas será isso necessariamente uma evidência de sua degeneração hereditária? O termo degenerado é aplicado tão livre e amplamente por alguns autores modernos, que 


\section{CLÁSSICOS DA PSICOPATOLOGIA}

não se pode deixar de concluir que eles classificam como tal todos aqueles que não se conformam a algum tipo primitivo e selvagem possuidor de um sistema nervoso imperfeitamente desenvolvido.

\section{Referências}

1. “Les obsessions”, par M. le Dr. van Eeden, d'Amsterdam. (Communication faite à la séance d'hiver de la Société des Psychiatres, à Utrecht, novembre, 1890.) Revue de l’hypnotisme, 1892, vol. vi, p. 5. 2. "Un cas de claustrophobie guéri par la suggestion hypnotique", par le Dr. Gorodichze. Revue de l'hypnotisme, vol. viii, p. 53.

3. "Les phobies neurasthéniques envisagées au point de vue du service militaire", par le Dr. Bérillon, médecin inspecteur adjoint des asiles publics d'aliénés de la Seine. Revue de l'hypnotisme, 1894, vol. viii, p. 241.

4. "Les pseudo-phobies", par M. le Dr. Gélinea. Revue de l'hypnotisme, 1894, vol. viii, p. 353.

5. "Phobies neurasthéniques envisagées au point de vue professionnel”, par le Dr. Edgar Bérillon. Revue de l'hypnotisme, August, 1894, vol. ix, p. 33.

6. "La folie du doute et le délire du toucher", par M. le Docteur Ladame de Genève. Revue de l'hypnotisme, 1891, vol. v, p. 130.

7. "Monomanie suicide guérie par la suggestion pendant l'état de sommeil provoqué", par M. le Dr. Liébeault. International Congress of Experimental Psychology. Second Session, London, 1892, p. 145.

8. "Psycho-Thérapie", par les Docteurs A. W. van Renterghem et F. van Eeden. Paris, 1894.

9. "Hypnotisme, suggestion, psychothérapie", Etudes nouvelles par le Dr. Bernheim, Professeur à la Faculté de Médecine de Nancy. Paris, 1891.

10. "Valeur thérapeutique de la suggestion dans quelques psychoses", par le Docteur de Jong (de la Haye). Comptes rendus du premier Congres International de l'hypnotisme experimental et thérapeutique. Paris, 1889, p. 196.

11. "Guérison par la suggestion hypnotique d'idées délirantes et de mélancholie avec conscience”, par M. le Docteur Jules Voisin, médecin de la Salpêtrière. Revue de l'hypnotisme, 1888, vol. ii, p. 242. 12. "Application de l'hypnotisme au traitement des maladies mentales", par M. le Dr. Burckhardt, directeur de l'asile d'aliénés de Préfargier (Suisse). Revue de l'hypnotisme, 1889, vol. iii. p. 56.

13. "Manie hystérique avec impulsions et hallucinations guérie par la suggestion", par le Docteur P. Burot, professeur à l'ècole de Rochefort. Revue de l'hypnotisme, 1889, vol. iii, p. 336.

14. “Quelques considérations sur la psychologie de l'hypnotisme à propos d'un cas de monomanie guérie par suggestion”, par M. Delboeuf, professeur à l'Université dc Liège. Revue de l'hypnotisme, 1893, p. 200. 15. "Les neurasthéniques et la suggestion. - Agoraphobie traitée avec succès par la suggestion", par M. le Docteur Antoine Mavroukakis. Revue de l'hypnotisme, 1893, vol. ii, p. 374.

16. "Jalousie morbide, compromettant la vie, guérie par la suggestion”, par M. le Dr. Bourdon, do Méru. Revue de l'hypnotisme, 1894, vol. iii, p. 141.

17. "Der Hypnotismus und seine Anwendung in der praktischen Medicin", von Dr. Med. Otto G. Wetterstrand in Stockholm. Wien und Leipzig, 1891.

18. "Die Suggestions-Therapic bei krankhaften Erscheinungen des Geschlechtsinnes", von Dr. A. Freiherrn von Schrenck-Notzing, Prakt. Arzt in München. Stuttgart, 1892. 
19. "Der Hypnotismus, seine psycho-physiologische, medicinische, strafrechtliche Bedeutung und seine Handbabung", von Dr. August Forel, Professor der Psychiatrie und Director der kantonalen Irrenanstalt in Zürich. Stuttgart, 1891.

20. "Hypnose und Suggestion im Dienste der Heilkunde", von Dr. Ewald Hecker, Spezialarzt für Nervenkrankheiten in Wiesbaden und Johannisberg am Rhein. Wiesbaden, 1893.

21. "Erfolge des therapeutischen Hypnotismus in der Landpraxis", von Dr. Georg Ringier. München, 1891.

22. "Casuistische Mittheilungen über Suggestionstherapie", von Dr. F. Scholz, Director der Krankenanstalt zu Bremen. Zeitschrift für Hypnotismus, February, 1893, p. 172, 187.

23. "Ein Beitrag zur psychischen und suggestiven Behandlung der Neurasthenie", von Dr. Freiherrn von Schrenck-Notzing. Zeitschrift für Hypnotismus, December, 1893, p. 94.

24. "The use of suggestion of the first degree, as a means of modifying or of completely eliminating a fixed idea", by Russell Sturgis, M.D., Boston. Medical Record, New York, February 17, 1994.

25. "Hypnotism", by Albert Moll (of Berlin). London, 1890.

26. "The Psychology of the Attention", by Th. Ribot. London, 1890.

27. "Imperative Ideas”, by D. Rack Tuke, M.D., Brain, Part II, 1894, p. 179.

J. Milne Bramwell 